\title{
Seasonal variability of phytoplankton fluorescence in relation to the Straits of Messina (Sicily) tidal upwelling
}

\author{
F. Azzaro, F. Decembrini, F. Raffa, and E. Crisafi \\ Institute for Coastal Marine Environment, CNR, Sp. S. Raineri, 86 - 98122 Messina, Italy \\ Received: 11 April 2007 - Published in Ocean Sci. Discuss.: 2 May 2007 \\ Revised: 26 July 2007 - Accepted: 2 October 2007 - Published: 11 October 2007
}

\begin{abstract}
In the Straits of Messina, large gradients of tidal displacements, as well as the topographic constrictions, determine the upwelling of deeper waters in the surface layer. This work describes the seasonal variability in the surface distribution of phytoplankton biomass depending on the upwelling phenomena. Temperature, salinity, nitrates and phytoplankton fluorescence were measured in 1994 and 1995 by continuous underway surface real-time measurements onboard dedicated research boats. Each survey was performed following the dynamic phases of flooding and ebbing tides. Tidal currents are essentially southward during high tide and northward during low tide.
\end{abstract}

During the low water slack tide, large spatial gradients of physical-chemical and biological parameters were found, while at the high water slack tide, a diffused phytoplankton fluorescence was observed only in autumn due to a seasonal thermocline. Salinity, nitrate and chlorophyll- $a$ fluorescence data revealed a significant positive intercorrelation, whereas they were inversely correlated with temperature. Generally, the upwelling distribution was limited to narrow zones during winter, while in summer it was found in the middle of the Straits and in the southern zones. During spring in the southern zone of the Straits, the maximum chlorophyll- $a$ fluorescence was detected (May 1995, $0.32 \mu \mathrm{g}$-Chla $\mathrm{l}^{-1}$ ); in summer, when back and forth tidal movements between the Tyrrhenian and the Ionian seas intensify, decreased values were observed throughout the study area.

The data set obtained through continuous and repeatable samplings has allowed the study of different time-space scales in the Straits of Messina, a very strong and dynamic environment.

The Straits system could be compared to an "intermittent pump" which, during the different seasons, initially enriches itself and subsequently provides nutrients to the surrounding basins.

Correspondence to: F. Azzaro

(filippo.azzaro@iamc.cnr.it)

\section{Introduction}

Hydrodynamical processes affect the spatial distribution and temporal development of phytoplankton biomass on the world's oceans and seas. Among the hydrological events, the divergent current bring nutrients into the upper layer of the water column and modulates the chlorophyll- $a$ distribution (Koike et al., 1982; Echevarría et al., 2002; Gomez et al., 2004; Kontoyiannis et al., 2005). Upwelling is a hydrological phenomenon that strongly impacts the marine ecosystem. In fact, upwelling systems belong to the most productive marine environments, and are characterized by increased 'biological richness' in all levels of the trophic chain. Low water temperature is one of the indicators of upwelling, and the difference of sea-surface temperatures between an upwelling zone and the surrounding waters is a parameter for defining upwelling intensity (Levasseur et al., 1987; Lee et al., 1997; Tang et al., 2004; Reul et al., 2005). In these environments, phytoplankton growth is primarily regulated by the availability of allochthon nutrients, primarily nitrates, which stimulate the production of phytoplankton (Ruiz et al., 2001; Chen et al., 2004).

\subsection{Description of the study area}

The Straits of Messina, at the center of the Mediterranean Sea (Fig. 1a), is an area where strong currents determine fast changes in the oceanographic conditions. This system, separating the Italian peninsula from Sicily, is an amphidromic point for the tides of the Tyrrhenian in the northwest and the Ionian seas in the southeast (Fig. 1b). Morphologically, the Strait resembles a funnel-shaped geometry with a northsouth length of $40 \mathrm{~km}$ and a west-east width ranging from $3 \mathrm{~km}$ near the Tyrrhenian edge, to about $25 \mathrm{~km}$ at the Ionian open boundary. The narrowest section (Ganzirri-Punta Pezzo), which coincides with the sill region, has a depth of $\sim 80 \mathrm{~m}$ and divides the area into northern and southern sectors. The sea bottom slopes steeply downward to a depth of

Published by Copernicus Publications on behalf of the European Geosciences Union. 


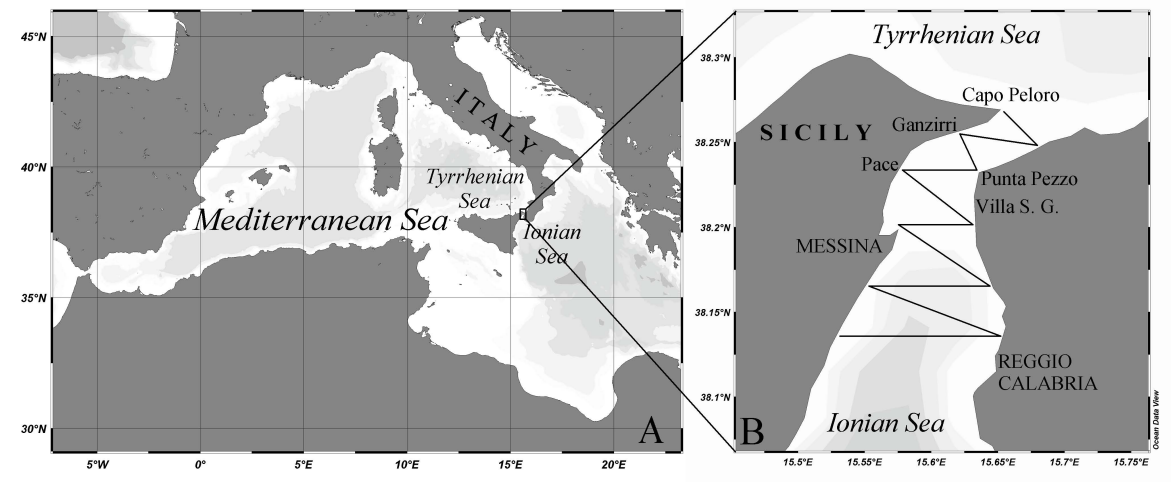

Fig. 1. Geographical location of the Straits of Messina (A) and automatic surface tracking (B).
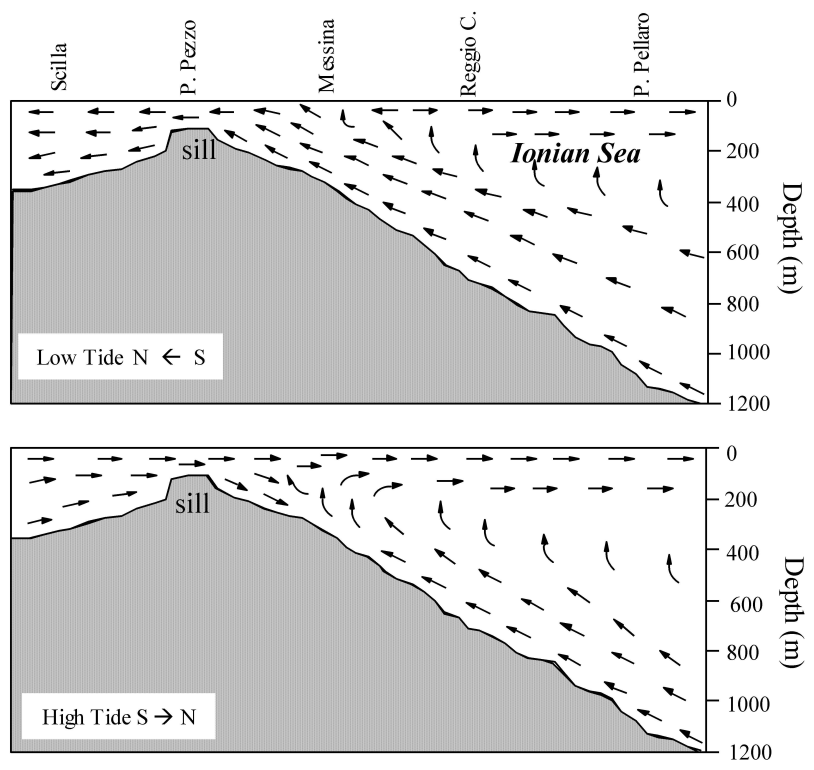

Fig. 2. Straits of Messina: schematic distribution of the tidal currents during the maximum speed in the low and high tide flow (Vercelli, 1925). Sill location refer to Fig. 3.

$1000 \mathrm{~m}$ at $19 \mathrm{~km}$ south of the sill. The northern sector has a gentler slope, and the $400 \mathrm{~m}$ isobath is located $15 \mathrm{~km}$ north of the sill toward the Tyrrhenian Sea. The Straits exhibits strong tidal currents driven by both barotropic and baroclinic processes, due to strong bathymetric constraints exerted by the sill and coastal morphology (Hopkins et al., 1984; Farmer et al., 1995; Farmer et al., 2002; Vargas-Yáñez et al., 2002). Large gradients of tidal displacements are encountered in the Straits of Messina, because the predominantly semi-diurnal north and south tides are approximately in phase opposition. Due to both phase opposition and topographic constrictions, the current velocities can attain values as high as $3.0 \mathrm{~m} \mathrm{~s}^{-1}$ in the sill region, and are related to the position of the sun, the phase of the moon, the wind speed and direction, and the air pressure distribution (Vercelli, 1925; Defant, 1961). Sur- face water turbulence in the Straits is mainly influenced by two types of circulation, a steady surface current and a turbulent mixing, both of which generate discontinuity of the thermo-haline distribution in the surface layer (Fig. 2). The steady current has a maximum speed of $2 \mathrm{~m} \mathrm{~s}^{-1}$ and a prevalently north to south direction at the surface $(0-30 \mathrm{~m})$. Water turbulence is caused both by internal waves and by tidal currents (Alpers and Salusti, 1983; Griffa et al., 1986; Di Sarra et al., 1987; Sapia and Salusti, 1987; Bignami and Salusti, 1990; Nicolò and Salusti, 1991; Alpers et al., 1996; Brandt et al., 1997; Brandt et al., 1999). Internal waves are caused by differences in water mass densities of the two basins that are facing in the Straits. Tidal currents are caused by opposite tidal oscillations of the two basins $(\max 27 \mathrm{~cm}$ ) with almost the same amplitude and period (about $61 / 4 \mathrm{~h}$ ). These conditions lead to the upwelling of deeper water of Levantine Intermediate Water origin (Cortese and De Domenico, 1990), which is colder, more salty and more nutrient-rich compared to the Tyrrhenian Surface Waters (Atlantic Water origin). Harmonic oscillations of the current flowing from the Tyrrhenian Sea waters into the Ionian Sea (high tide current), and from the Ionian water into the Tyrrhenian Sea (low tide current) are encountered, with a brief slack water interval (balancing flow).

Because of these particular environmental features, the Straits have been studied by many researchers in order to define forcing factors that determine its current regimen (cf., Vercelli, 1925; Vercelli and Picotti, 1926; Defant, 1940; Del Ricco, 1982; Tomasin and Tomasino, 1983; Böhm et al., 1987; Mosetti, 1988; Androsov et al., 1994; Androsov et al., 2002). Many hydrobiological studies have been conducted over the last few decades to describe the influence of complex hydrodynamic conditions on biological parameters (De Domenico, 1987; Bruni et al., 1988; Genovese et al., 1984; De Domenico et al., 1988; Magazzù et al., 1987; 1989; 1995; Guglielmo et al., 1995; Decembrini et al., 1998; 1999; Azzaro et al., 2004a; 2004b). 


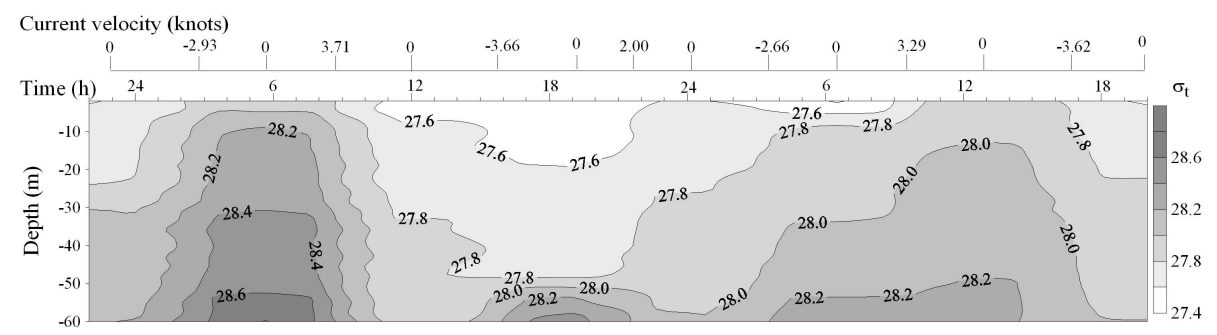

Fig. 3. 48-h behaviour of density at sill station surveyed with a frequency of 1-h at syzygy (December 1993). Estimated current direction $(+=\mathrm{S} \rightarrow \mathrm{N} ;-=\mathrm{N} \rightarrow \mathrm{S})$ and speed (Knots) from "Tavole di Marea I.I.M.M.". Reference to Fig. 2.

\subsection{Background and approache}

The majority of previous hydrological research has been conducted along the principal north-south axis using traditional oceanographic methods that, due to the time limitations of sampling, have produced an incomplete characterization of the horizontal extent and timing of the variability of the Straits of Messina. In recent years, oceanographic investigations using innovative strategies and techniques have led to the observation of the upwelling of deeper water, not only in restricted zones (sill), but also in the wider areas of the system. These recent contributions have led to a better understanding of the system (Azzaro et al., 1995; Cescon et al., 1997; Azzaro et al., 2000), but despite the development of new study approaches, prove to be limited in time. Conceivably, the concomitant ubiquitousness of water currents of different densities in the Straits, provokes natural vertical instability and an increase of deeper waters (upwelling). A conventional 48-h hydrological survey (with a 1-h sampling interval) in a fixed sill station is representative of the frequent upwelling occurrence, as indicated by the detected density inversion (see the example of Fig. 3). It is then assumed below that the timing of these overturns is highly coincident with the slack water interval when the rearrangement of the stable water column occurs as a result of instability. Near the end of the advective unsteadiness and during the onset of water slack, natural vertical vorticity and turbulent tidal currents occur. Flow continuity requires an upward flow from deeper waters to the south to maintain the divergence. As the vorticity and the associated cyclonic meander dissipate, upwelling should cease. The subsequent tidal stream could sweep the cold anomaly out of the Straits, and cause the temperature to rise again, setting the stage for the next tidal event.

A data set from continuous and repeatable sampling of water temperature and chlorophyll- $a$ fluorescence has allowed the study of different time-space scales in the Straits of Messina.

Due to high hydrodynamic system variability, the surface tracking was performed during the slack water, when the advective current can be considered negligible and the turbulent moving water is replaced by upwelling water. Not surprisingly, temperature records indicate that this is the onset of massive upwelling of cold water from depths. In fact, the more evident chemical-physical and biological variation was observed during the rise of deeper waters.

The aim of the present study was to assess the seasonal influence of the strong tidal variability on the surface phytoplankton distribution (estimated as chlorophyll- $a$ fluorescence) in the water upwelling into the Straits of Messina system. The results covered an annual cycle at monthly scale, narrowly focused on providing a first-order description of the observed seasonal variability of the physico-chemical and biological parameters.

\section{Materials and methods}

Spatial and temporal distribution patterns of physicochemical (temperature, salinity, and nutrient concentrations) and biological (chlorophyll- $a$ measured by in situ fluorescence emission) parameters were monitored for 25 months during a local research project, and data are presently available for the central-northern side of the Straits of Messina. Discrete water samples (nutrients, chlorophyll-a, etc.) based on conventional methods were collected during the surveys. The wind, air temperature and pressure were measured during each hydrographic cruise. Automatic real-time data were obtained by monthly surface tracking, from December 1993 to December 1995, in the area between Capo Peloro (Sicily) to the north and Reggio Calabria to the south. This area was covered on the R/B "Delfo" using zigzag cruise tracks between the Calabrian and Sicilian coasts, adopting the lagrangian method in order to follow the wave of tide in the Strait. The location of the area and the track followed by the boat in each survey is displayed in Fig. 1b. It is well known that the maximum intensity $(>3 \mathrm{~m} / \mathrm{s}$ ) of the tidal currents occur during spring tides, corresponding to syzygy lunar phases. Measurements were carried out when the water slackens during the spring tide period to individuate the upwelling of deeper waters. Prior to taking measurements, the current forecast from "Tide tables of the Istituto Idrografico della Marina, Genova" was used in order to seize the quasi-stationary situations following the dynamic phases of 

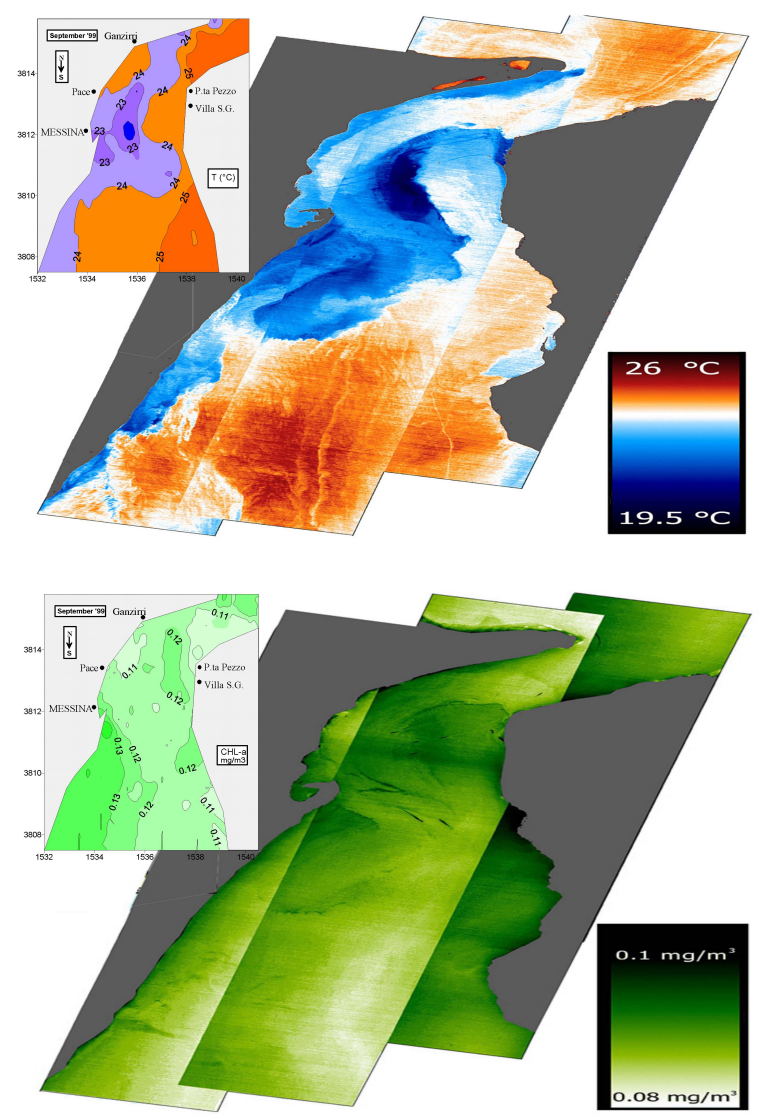

Fig. 4. Map comparison of surface water temperature and chlorophyll- $a$ fluorescence produced by data of sailing boat (left) with airborne images (MIVIS, right) data (25 September 1999).

high (high tide current, $3 \mathrm{~h} /$ cruise) and low (low tide current, $3 \mathrm{~h} /$ cruise) tides.

The above-mentioned local sampling strategy (Fig. 4) was recently repeated, and results showed that the images obtained simultaneously by MIVIS (Multispectral Infrared Visible Imaging Spectrometer) can be superimposed onto the measures at sea as reported in Azzaro et al. (2001).

Seasonal real-time tracking of surface water temperature, salinity and fluorescence by chlorophyll- $a$ were automatically measured (at a frequency of $30 \mathrm{~s}$ ) using a CTD probe (Meerestechnik Elektronik) implemented with a fluorometer (Haardt-1101LP). The sensors were positioned inside a steel tank where the water flowed, drawn by a membrane pump at the back of the system; the sensors outputs were transmitted to a computer for display and storage. In addition to the above parameters, nitrate-nitrite automatic assays were performed in the winter and spring of 1994 (at a frequency of $30 \mathrm{~s}$ ) in two different surveys onboard the R/V "Urania" using an Alliance Integral analyzer (analytical accuracy of $0.15 \mu \mathrm{M})$. CTD-Fl data quality for salinity, fluorescence by chlorophyll- $a$ and nitrate were assessed by com-

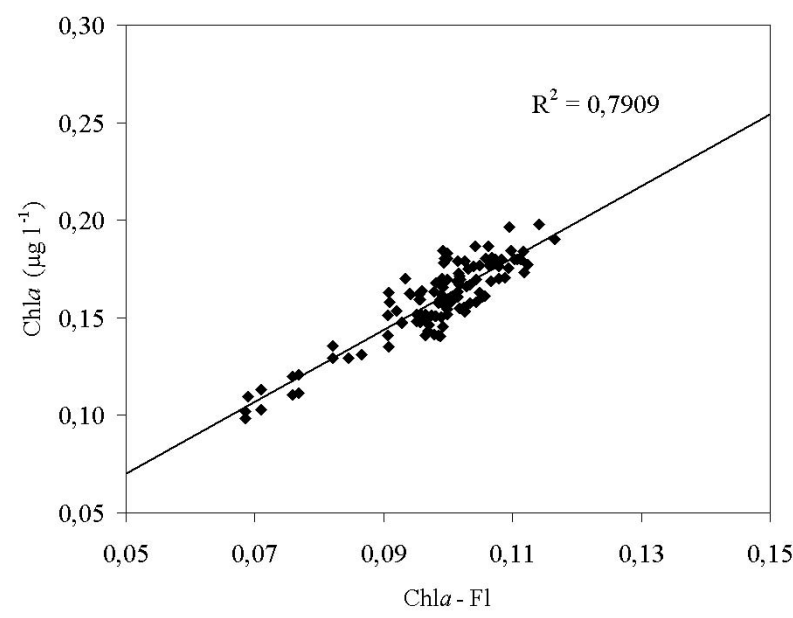

Fig. 5. Plot of chlorophyll-a concentration versus chlorophyll-a fluorescence.

parison with laboratory analysis (according to Strickland and Parsons, 1972; Innamorati et al., 1990; Grasshoff, 1983). As it shown in Fig. 5, the scatter plot demonstrates evident correlation between chlorophyll $-a$ fluorescence and concentration.

\section{Results and discussions}

As a part of several studies related to the influence of the physical forcing on the first level of the trophic chain, the hydro-biological behavior of surface waters from December 1993 to December 1995 are presented. The seasonal average and standard deviation of measured parameters during the slack water after low tide flow (low water slack) and after high tide flow (high water slack) are reported in Table 1 . Nitrate and salinity trends in winter and spring seasons are shown to point out the upwelling process. Among the cruises, four monthly surveys both in low and in high tides were chosen in order to represent the seasonal phytoplankton fluorescence and temperature conditions depending on the tidal current pattern.

\subsection{Nitrate and salinity distributions}

The high frequency real-time measurements of surface nitrates and salinity distributions observed in December 1993 and April 1994 are shown in Fig. 6. In the winter season during the low water slack tide, the maximum nitrate concentrations were found along the Sicilian $(1.51 \mu \mathrm{M}-$ Pace $)$ and Calabrian coasts (1.36 $\mu \mathrm{M}$ - Punta Pezzo) and were associated with the maximum salinity (38.24) and the minimum temperature $\left(15.3^{\circ} \mathrm{C}\right)$. In the high water slack tide, the nitrate concentration increase was located near Villa S. Giovanni (1.2 $\mu \mathrm{M}$ of $\mathrm{NO}_{3}$ and salinity of 38.22). Lower nitrate 

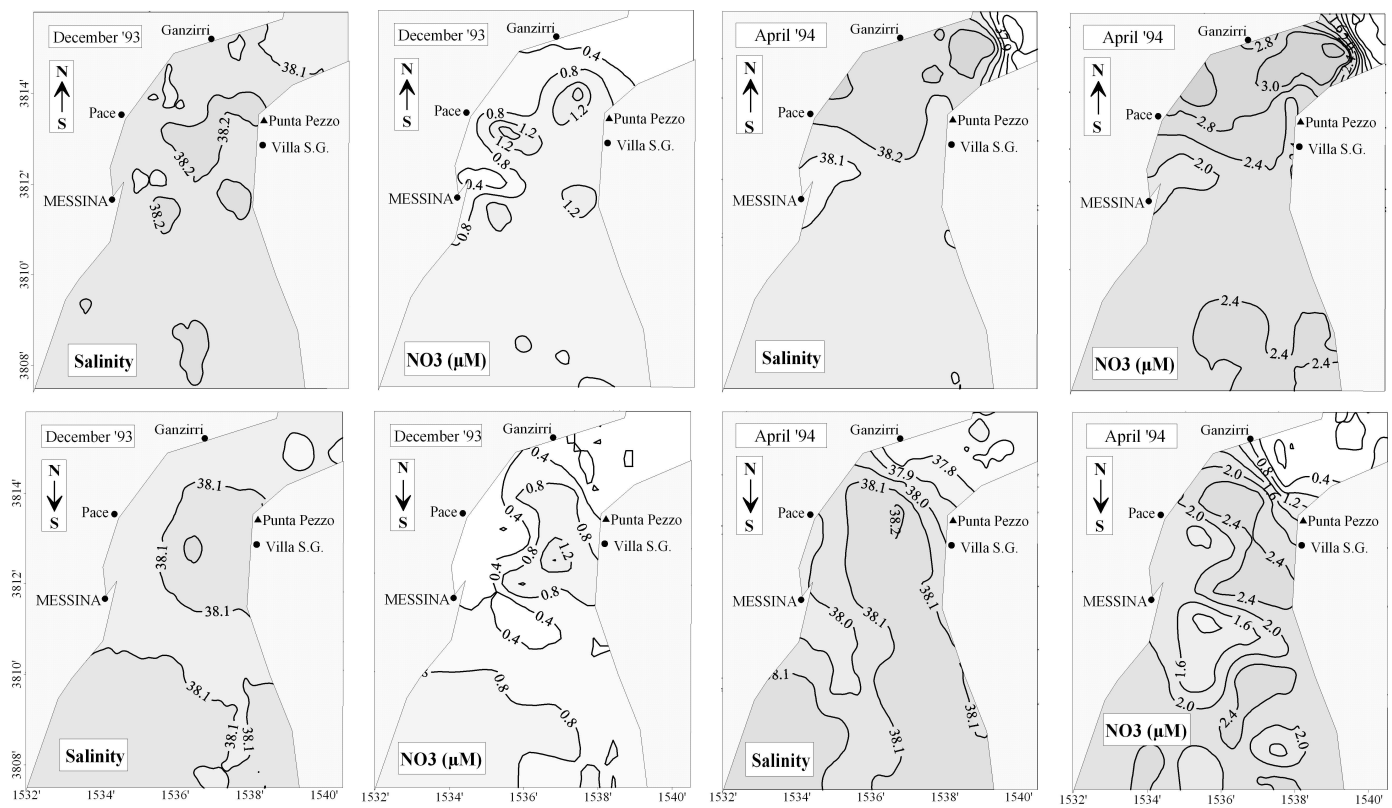

Fig. 6. Effect of diurnal variability of spring-tide on the surface distribution of salinity (left) and nitrate ( $\mu \mathrm{M}$, right) during December 1993 and April 1994 in the slack water after low tide (upper panel) and high tide currents (lower panel).

Table 1. Seasonal (1994-95) average and standard deviation (sd) of temperature, salinity, chlorophyll- $a$ fluorescence in the slack water after low and high tide currents.

\begin{tabular}{lllllll}
\hline \multirow{2}{*}{ Seasons 1994-95 } & \multicolumn{2}{c}{ Low Water Slack - mean (sd) } & \multicolumn{2}{c}{ High Water Slack - mean (sd) } \\
\cline { 2 - 7 } & Temp. ${ }^{\circ} \mathrm{C}$ & Salinity & $\mu \mathrm{g}$-Chl $a 1^{-1}$ & Temp. ${ }^{\circ} \mathrm{C}$ & Salinity & $\mu \mathrm{g}-\mathrm{Chl} a 1^{-1}$ \\
\hline $\begin{array}{l}\text { Winter } \\
\text { (Dec-Jan-Feb) }\end{array}$ & $15.30(0.56)$ & $37.90(0.51)$ & $0.16(0.05)$ & $15.50(0.70)$ & $37.77(0.47)$ & $0.16(0.04)$ \\
$\begin{array}{l}\text { Spring } \\
\text { (March-April- }\end{array}$ & $15.85(1.06)$ & $38.05(0.28)$ & $0.26(0.24)$ & $16.05(0.78)$ & $37.80(0.42)$ & $0.10(0.08)$ \\
$\begin{array}{l}\text { May) } \\
\text { Summer }\end{array}$ & $19.80(5.93)$ & $38.08(0.39)$ & $0.07(0.03)$ & $25.40(3.57)$ & $37.90(0.56)$ & $0.06(0.05)$ \\
$\begin{array}{l}\text { June-July-Aug) } \\
\text { Autumn } \\
\text { (Sep-Oct-Nov) }\end{array}$ & $20.75(2.47)$ & $37.98(0.47)$ & $0.14(0.13)$ & $20.16(2.59)$ & $38.01(0.28)$ & $0.16(0.03)$ \\
\hline
\end{tabular}

concentrations, close to undetectable values and associated with a salinity of 37.50 , were measured in the northern zone of the Straits.

During the spring season surveys, higher nitrate concentrations and wider upwelling zones were detected compared to winter surveys. Major $\mathrm{NO}_{3}$ values during spring $(3.67 \mu \mathrm{M})$ in the low water slack were associated with maximum salinity (38.39) and were located between Capo Peloro and Punta Pezzo, while the highest concentration $(2.81 \mu \mathrm{M})$ was recorded between Pace and Punta Pezzo at the high water slack.

The correlation analyses of nitrate concentration and thermo-haline parameters showed direct correlations with salinity $(\mathrm{r}=0.52, \mathrm{p}<0.01, \mathrm{n}=1560)$, and an inverse correlation with temperature $(\mathrm{r}=0.84, \mathrm{p}<0.01, \mathrm{n}=1560)$, (Fischer, 1946). A direct correlation ( $n=1560$ December ' 93 and April '94) was observed between chlorophyll- $a$ fluorescence and salinity $(\mathrm{r}=0.22 \mathrm{p}<0.01)$ and nitrate levels $(\mathrm{r}=0.12 \mathrm{p}<0.01)$, while an inverse correlation was observed with temperature $(\mathrm{r}=0.23 \mathrm{p}<0.01)$. It is likely that tidal pumping is an important contributor to the nutrient supply of this area, which suggests that the $\mathrm{NO}_{3}$ concentration could be a conservative parameter of the upwelled water in the Straits of Messina (De Domenico M. et al., 1988). Upwelled water is cooler and saltier than the original surface water, and has much higher concentrations of nutrients such as nitrate, which 

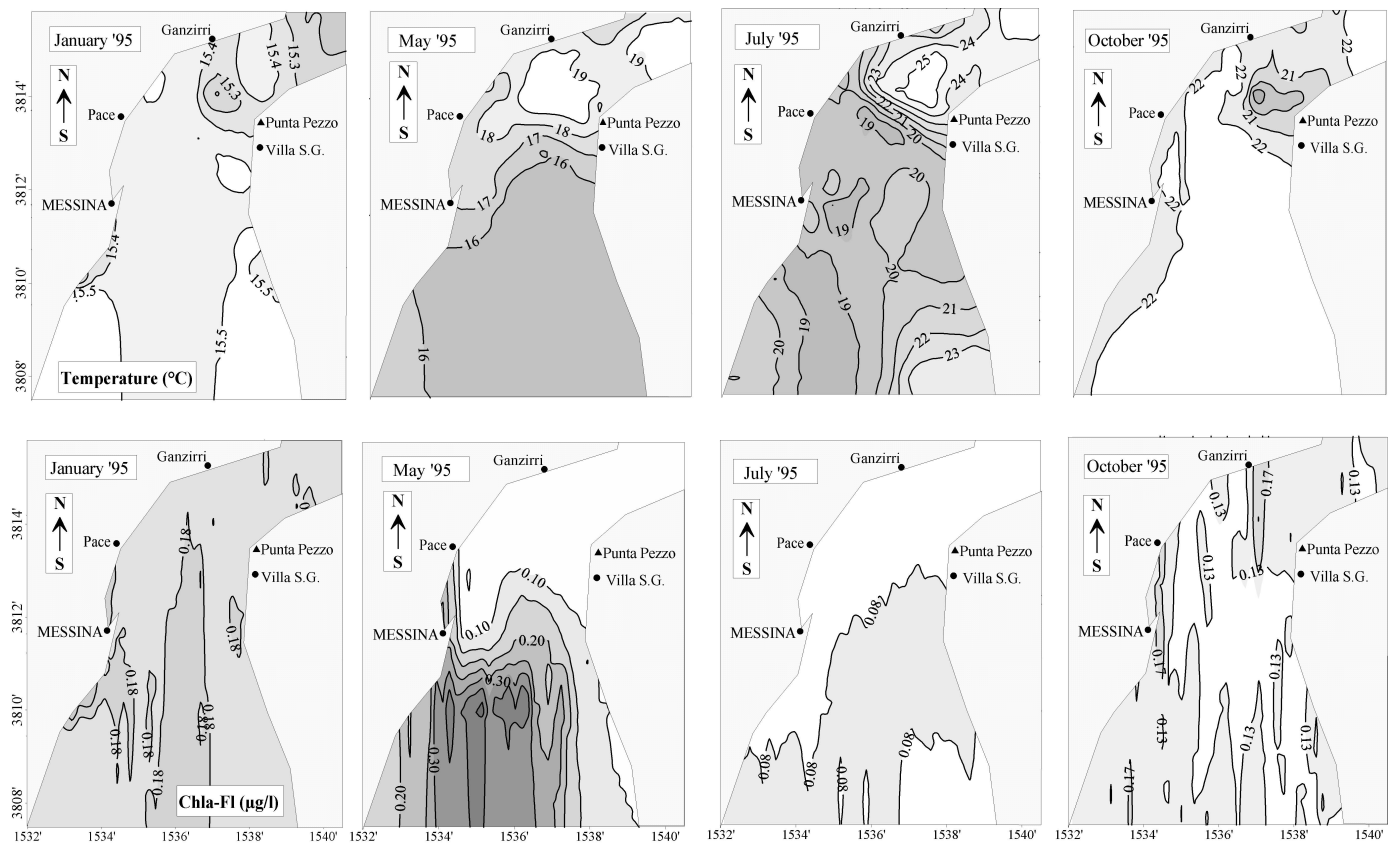

Fig. 7. Effect of diurnal variability of spring-tide on the surface distribution of temperature $\left({ }^{\circ} \mathrm{C}\right.$, upper panel) and chlorophyll- $a$ fluorescence ( $\mu \mathrm{g}-\mathrm{Chl} a 1^{-1}$, lower panel) during January, May, July and October 1995 in the slack water after low tide current.
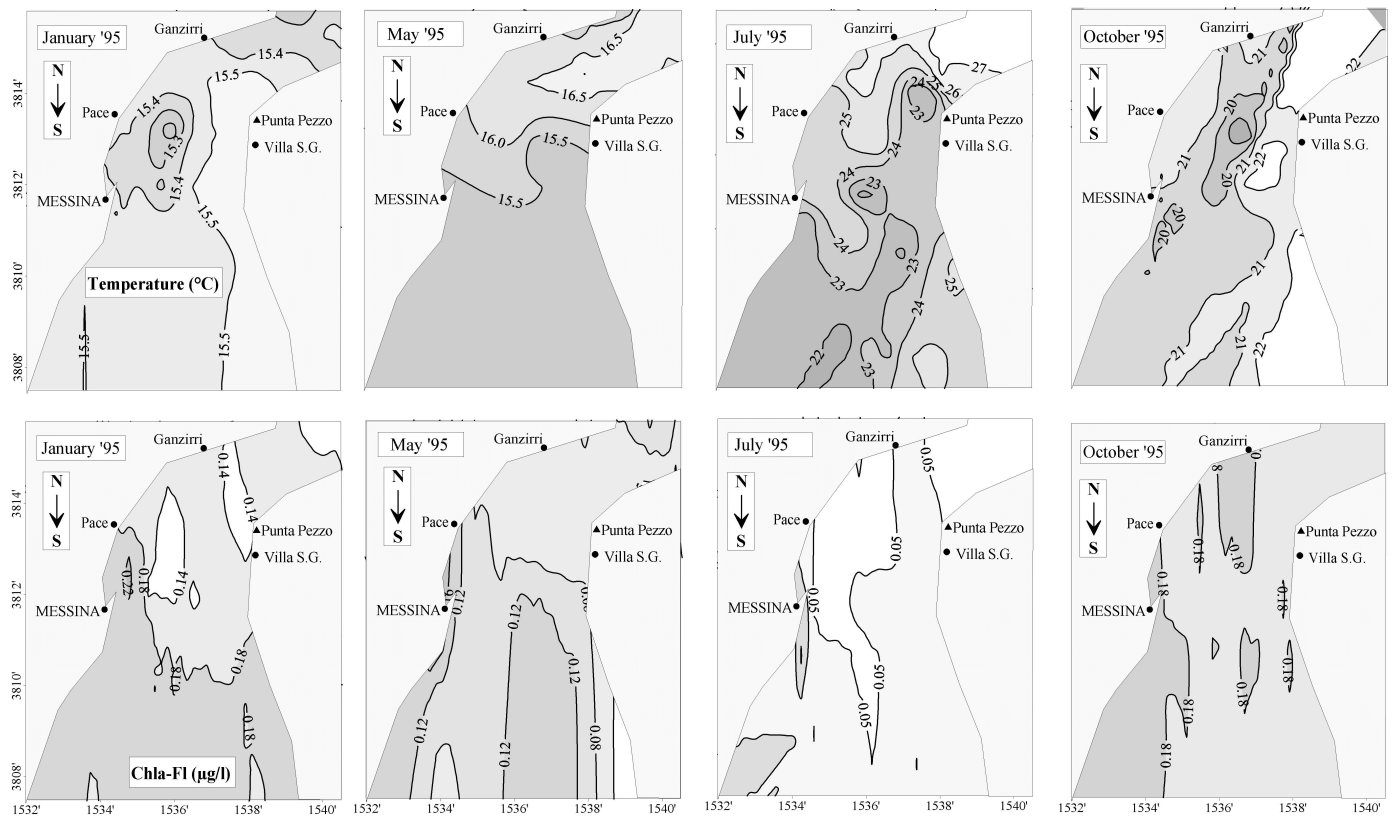

Fig. 8. Effect of diurnal variability of spring-tide on the surface distribution of temperature $\left({ }^{\circ} \mathrm{C}\right.$, upper panel) and chlorophyll- $a$ fluorescence ( $\mu \mathrm{g}-\mathrm{Chl} a 1^{-1}$, lower panel) during January, May, July and October 1995 in the slack water after high tide current.

sustain the biological primary production. The high values of chlorophyll- $a$ fluorescence at the boundary of the divergence zone are likely determined by the upward flux of nutrients to the euphotic zone and by the intense tidally-induced vertical mixing.

\subsection{Seasonal trend of phytoplankton fluorescence and tem- perature distribution}

The hydro-biological parameters recorded monthly during 1995 during both low and high water slack tide are described. The correlation matrices for both slack tides, based on 1000 
individual datapoints for each component (Table 2), show some significant correlations. Thus, during spring, summer and fall seasons, fluorescence is positively correlated with salinity and negatively correlated with temperature, while in winter the correlation is inverted in high water slack and in low water slack there is a lack of correlation. The spatial distribution among the different seasons is clear evidence of the tidally-induced upwelling character of the zone. The contour plots of sea-surface temperature and chlorophyll- $a$ fluorescence (SST and Chla-Fl hereinafter) and seasonal distribution patterns are displayed in Figs. 7 and 8.

General uniformity of the surface thermo-haline horizontal structures were observed during winter months in slack water; water temperature ranged between $14.35^{\circ} \mathrm{C}$ and $15.67^{\circ} \mathrm{C}$ $\left(\Delta \mathrm{T}=1.3^{\circ} \mathrm{C}\right)$, and salinity ranged from 37.44 to 38.12 . In the low water slack tide, SST was lower $\left(15.30^{\circ} \mathrm{C}\right.$ in January 1995; Fig. 7) in the northern zone bounded by the GanzirriPunta Pezzo section. In the high water slack, SST was found to be lower $\left(15.20^{\circ} \mathrm{C}\right.$ in January 1995 ; Fig. 8) mainly in the central zone along the Sicily coast. During winter, phytoplankton fluorescence was low and was uniformly distributed in the area (around $0.16 \mu \mathrm{g}$-Chla ${ }^{-1}$ ) in both slack waters (Figs. 7 and 8). However, in the low water slack tide, a slight increase in the Chla-Fl concentration at the middle of the southern zone and in the western part of the central zone were found, whereas at high water slack tide (Fig. 8) in the upwelling zone, between Ganzirri-Punta Pezzo, a decrease of Chla-Fl values was measured $\left(0.14 \mu \mathrm{g}-\mathrm{Chla}^{-1}\right)$.

During the spring season, the upwelling zone found in the winter gradually extended to the south $\left(15.50^{\circ} \mathrm{C}\right.$ in May 1995; Fig. 7) during both low and high slack waters. In particular, during low water slack tide (Fig. 7), the maximum phytoplankton fluorescence $\left(0.32 \mu \mathrm{g}\right.$-Chla $\left.{ }^{-1}\right)$ was recorded in the southern part, whereas in the high water slack, ChlaFl was extremely low with a slight increase in the southern sector $\left(>0.12 \mu \mathrm{g}\right.$-Chla $\left.{ }^{-1}\right)$.

The maximum SST range occurred in the low water slack after higher currents velocity $(>2 \mathrm{~m} / \mathrm{s})$ during the summer; a narrow temperature front $\left(25.53-18.54^{\circ} \mathrm{C}\right)$ (Fig. 7) and salinity front (37.80-38.35) were found in the northern zone of the system. In the opposing current phase (high water slack; Fig. 8), SST ranged between $27.93^{\circ} \mathrm{C}$ and $22.88^{\circ} \mathrm{C}$ and the salinity ranged from 37.50 to 38.30 . Moreover, the upwelling zone mainly extended along the Sicilian coast, while higher temperature values were recorded in the northern zone $\left(27.93^{\circ} \mathrm{C}\right)$ (Fig. 8). During summer, lower Chla-Fl values $\left(<0.0 \mu \mathrm{g}-\mathrm{Chla} \mathrm{l}^{-1}\right)$ were registered coincident with highest surface thermo-haline discontinuities at slack water after both tidal flows and were localized in the southeastern area.

In autumn, SST values were influenced by summer heating, and consequently there were higher annual averages with less variation $\left(20.75 \pm 2.47^{\circ} \mathrm{C}\right)$. Moreover, in October, the previously described phytoplankton fluorescence conditions become inverted (Fig. 8): at low water slack high tide,
Table 2. Correlation matrix for the seasonal (1994-95) data: low water slack (upper right); high water slack (lower left); number of data for each set: $>1000$. Significance of correlation coefficients: $\mathrm{r}=0.062(\mathrm{P}=0.05) ; \mathrm{r}=0.081(\mathrm{P}=0.01)$.

\begin{tabular}{cccc}
\multicolumn{3}{l}{ Winter (Dec-Jan-Feb) } \\
\hline & $T$ & $S$ & $F$ \\
\hline$H W S$ & & & $L W S$ \\
$T$ & & -0.052 & 0.020 \\
$\mathrm{~S}$ & -0.101 & & -0.050 \\
$\mathrm{~F}$ & 0.370 & -0.319 & \\
& & & \\
\hline
\end{tabular}

\begin{tabular}{cccc}
\multicolumn{3}{l}{ Spring (Mar-Apr-May) } \\
\hline \multicolumn{3}{c}{$T$} & \multicolumn{2}{l}{ S } & $F$ \\
\hline$H W S$ & & & $L W S$ \\
$\mathrm{~T}$ & & -0.393 & -0.686 \\
$\mathrm{~S}$ & -0.481 & & 0.219 \\
$\mathrm{~F}$ & -0.584 & 0.133 & \\
& & & \\
\hline
\end{tabular}

\begin{tabular}{cccc}
\multicolumn{3}{l}{ Summer (Jun-Jul-Aug) } \\
\hline \multicolumn{3}{l}{$T$} & \multicolumn{2}{l}{ S } & $F$ \\
\hline$H W S$ & & & LWS \\
$\mathrm{T}$ & & -0.126 & -0.556 \\
$\mathrm{~S}$ & -0.745 & & 0.366 \\
$\mathrm{~F}$ & -0.732 & 0.292 & \\
& & & \\
\hline
\end{tabular}

\begin{tabular}{|c|c|c|c|}
\hline \multicolumn{4}{|c|}{ Autumn (Sep-Oct-Nov) } \\
\hline & $T$ & $S$ & $F$ \\
\hline$H W S$ & & & LWS \\
\hline $\mathrm{T}$ & & -0.424 & -0.375 \\
\hline $\mathrm{s}$ & -0.707 & & 0.232 \\
\hline $\mathrm{F}$ & -0.560 & 0.370 & \\
\hline
\end{tabular}

values and homogeneous distributions $\left(0.13 \mu \mathrm{g}\right.$-Chla $\left.1^{-1}\right)$ were found; in the divergence areas, higher Chla-Fl values $\left(0.18 \mu \mathrm{g}\right.$-Chla $\left.1^{-1}\right)$ were observed at both slack waters. In fact, the distribution of biomass in autumn was influenced by the presence of a thermocline. A report by Brandt et al. (1999) on high-resolution hydrographical measurements carried out in October 1995 approximately at slack waters after both tidal flows, showed that when south of the Straits sill, the thermic profile was characterized by the presence of a well-mixed near-surface layer with a thickness of about 40 meters. The astronomic conditions imply that advective velocities of the waters are stronger in spring through late summer, which could favor some of the phenomena discussed here (greater shear, more mixing). On the other hand, the simultaneous development of the autumnal thermocline would hinder the pumping of nutrients and other particles into the euphotic zone from deep waters. These counteracting influences are likely responsible for the biological cycle of the layer over the thermocline itself, and any reliable description of the seasonal cycle requires more in situ data. Seasonal temperature and chlorophyll- $a$ maps (Figs. 7 and 8) suggest the following features during most of the year: Seasonal temperature depicts upwelling cores with cold and very rich in particles surface waters, but biologically poor patches. The chlorophyll- $a$ maps depict a southward tongue of water rich in chlorophyll- $a$ connected to the upwelling zone in such way that high chlorophyll- $a$ concentrations be found in calmer waters, far from the place where water upwells.

\section{Conclusions}

The seasonal variability of phytoplankton fluorescence showed low values in the tidally induced upwelling zone due to the strong vertical mixing, except during autumn, when thermocline is also present in the Straits and the exchange in the water column is limited (Magazzù et al., 1987). 
The data show the existence of an annual cycle with an upwelling peak in late spring through the late summer. During autumn and winter seasons, the water upwelling is confined to the central zone of the Straits. In spring, the divergence zones occur both in the central and southern sectors of the system. During the summer season, the water upwelling takes place in the middle area of the Straits spreading to the south.

The principal correlation features are consistent with the assumption that main variations in hydrobiological characteristics are directly related to the seasonal trends of the tide currents, strongly evident during warm seasons compared to the cold ones. Moreover, the lack of correlation in winter is due to the expected homoeothermy of the water column.

With respect to the whole area, ranges of surface physicalchemical and biological parameters increase after the low tide. The highest chlorophyll- $a$ fluorescence values were observed during the spring season in the low water slack, while the phytoplankton development is stimulated in the opposite high water slack one during autumn.

The effects of seasonal variability recorded in autumn, with the high occurrence of phytoplankton biomass in divergence zones, are caused by the formation of a thermocline layer with a lower intensity of upwelling processes (Brandt et al., 1999). The gradual warming and expansion of the surface layer establishes the stratification and nutrients are recycled in the upper layer (Magazzù et al., 1987). In stratified conditions, when the exchange in the water column is limited, nutrients are likely supplied to the photic level by lateral transport and faster remineralization above the thermocline. This particular combination means that phytoplanktonic organisms find optimal conditions for their growth at the surface layer, where there is low vertical mixing, and light and nutrient availability. In the summer months, despite the input of nutrient-rich deeper waters (Cescon et al., 1997), the low autotrophic biomass is due to high vertical hydrodynamics. Additional variability would be generated by wind force, incident irradiance, advection from adjacent areas, neither of which were a major factor of modulation of the hydrological conditions established from the course of the tides at the time of the present study. Although surface data alone are not enough to discriminate what physical process is forcing the biological response, mixing events at the sill region of the Straits of Messina are likely mechanisms for the fertilization of the upper layer. The evidence of mixing allows us to define the Straits as a pulsating upwelling area, because the mechanisms regulating the mixing events are tidally induced. As a formal model, the Straits of Messina may be compared to an 'intermittent pump', which compresses and nutrientenriches itself during the autumn and winter seasons, while in spring it releases and stimulates phytoplankton in both locally and adjacent zones (De Domenico et al., 1988; Azzaro et al., 1995; Magazzù et al., 1995; Decembrini et al., 1998; Kinder and Bryden, 1990). During the summer season, the surface water is enriched with nutrients and is advected to- wards the surrounding areas, where a decrease of nutrients and increase of chlorophyll- $a$ occurs, namely in the north (Gulf of Gioia Tauro; Innamorati et al., 1996) and along the southeastern Sicilian coast (Böhm et al., 1987; Decembrini et al., 2004; Raffa and Hopkins, 2004). In other marine ecosystems, low phytoplankton growth is due to nutrient depletion of the euphotic layer.

Acknowledgements. The authors thank G. Zappalà, an electronic engineer, A. Cosenza, an electronic technician, and F. Soraci, a vessel technician, for their valuable work in the field. The constructive criticisms of V. Martin-Jézéquel and of an anonymous reviewer on earlier versions of this work are gratefully acknowledged.

Edited by: E. J. M. Delhez

\section{References}

Alpers, W., Brandt, P., Rubino, A., and Backhaus, J. O.: Recent contributions of remote sensing to the study of internal waves in the Straits of Gibraltar and Messina. In: Briand, F. (Eds.), Dynamics of Mediterranean straits and channels. CIESM Science Series 2, Bull. Inst. oceanogr., Monaco, 17, 21-40, 1996.

Alpers, N. and Salusti, E.: Scylla and Charybdis observed from space, J. Geophys. Res., 88(3), 1800-1808, 1983.

Androsov, A. A., Voltzinger, N. E., Kagan, B. A., and Salusti, E.: Residual tidal circulation in the Straits of Messina, Phys. Atmos. Ocean, 29: 522-531, 1994.

Androsov, A. A., Kagan, B. A., Romanenkov, D. A., and Voltzinger, N. E.: Numerical modelling of barotropic tidal dynamics in the Straits of Messina, Adv. Water Resour., 25, 401-415, 2002.

Azzaro, F., Decembrini, F., and Crisafi, E.: Continuos survey of upwelling in the Straits of Messina, Rapp. Comm. Int. Mer Médit., 34, 167, 1995.

Azzaro F., Decembrini F., and Crisafi, E.: Sequenza temporale delle condizioni termo-aline e distribuzione della biomassa fotoautotrofa nello Stretto di Messina, Biol. Mar. Medit., 7(1), 541548,2000

Azzaro, F., Cavalli, R. M., Decembrini, F., Pignatti, S., and Santella, C.: Biochemical and dynamical characteristics of the Messina Straits water by means of hyperspectral data. Proceedings of SPIE, Hyperspectral Remote Sensing of the Ocean, edited by: Frouin, R. J., Kawamura, H., and Kishino, M., Sendai, Japan, 4154, 240-249, 2001.

Azzaro, F., Decembrini, F., Raffa, F., and Crisafi, E.: Hydrobiologic observations in the water column from the quadrature to the syzygy in the Straits of Messina, Biol. Mar. Medit., 11(2), 481-485, 2004a.

Azzaro, F., Decembrini, F., and Raffa, F.: Hydrobiologic observations in syzygy in a latitudinal section in the Messina Straits, Rapp. Comm. Int. Mer Médit., 37, 483, $2004 b$.

Bignami, F. and Salusti, E.: Tidal currents and transient phenomena in the Straits of Messina: A review, in: The Physical Oceanography of Sea Straits, edited by: Pratt, L. J., Kluwer Academic, Boston, 95-124, 1990.

Böhm, E., Magazzù, G., Wald, L., and Zoccoletti, M. L.: Coastal currents on the Sicilian shelf south of Messina, Oceanologica Acta, 10, 137-142, 1987. 
Brandt, P., Rubino, A., Alpers, W., and Backhaus, J. O.: Internal waves in the Straits of Messina studied by a numerical model and synthetic aperture radar images from the ERS $1 / 2$ Satellites, J. Phys. Oceanogr., 27(5), 648-663, 1997.

Brandt, P., Rubino, A., Quadfasel, D., Alpers, W., Sellschopp, J., and Fiekas, H.: Evidence for the influence of Atlantic-Ionian stream fluctuations on the tidally induced internal dynamics in the Straits of Messina. Notes and Correspondence, J. Phys. Oceanogr., 29, 1071-1080, 1999.

Bruni, V., Acosta-Pomar, M. L. C., and Maugeri, T. L.: Evolution des différentes populations microbiennes dans deux zone de la Méditerranée. Rapp. Comm. Int. Mer Médit., 31(2), 171, 1988.

Cescon, B., Azzaro, F., Creazzo, S., Decembrini, F., \& Magazzù, G: Processes affecting upwelling and primary productivity of the Straits of Messina. Bollettino di Geofisica Teorica e Applicata, 38 (1-2): 137-147, 1997.

Chen, C.-T. A., Hsing, L.-Y., Liu C.-L., and Wang, S.-L.: Degree of nutrient consumption of upwelled water in the Taiwan Strait based on dissolved organic phosphorus or nitrogen, Mar. Chem., 87(3-4), 73-86, 2004.

Cortese G. and De Domenico E.: Some considerations on the levantine intermediate water distribution in the Straits of Messina, Boll. Ocean. Teor. Appl., 8(3), 197-207, 1990.

Decembrini, F., Azzaro, F. Paschini, E., and Magazzù, G.: Influenza dei fenomeni di upwelling sulla produzione e biomassa fitoplanctoniche nello Stretto di Messina, Atti A.I.O.L, 12(2), 159-171, 1998.

Decembrini F., Azzaro F., and Leonardi M.: Variabilità a breve e lungo termine delle caratteristiche idrologiche nelle acque costiere di un sistema ad elevato idrodinamismo (Stretto di Messina), Atti A.I.O.L., 13(1), 151-158, 1999.

Decembrini, F., Hopkins, T. S., and Azzaro, F.: Variability and sustenance of the deep-chlorophyll maximum over a narrow shelf, Augusta Gulf (Sicily), Chemistry and Ecology, 20 (Supplement 1), S231-S247, 2004.

De Domenico, E.: Caratteristiche fisiche e chimiche delle acque nello Stretto di Messina. Doc. et Trav. IGAL, Paris, 11, 225-235, 1987.

De Domenico, M., Cortese, G., Pulicanò, G., and De Domenico, E.: Variazione spazio-temporale di nutrienti, clorofilla e carica microbica nelle acque dello Stretto di Messina, Atti A.I.O.L., 8(1), 337-355, 1988.

Defant, A.: Scilla e Cariddi e le correnti di marea nello Stretto di Messina, Geofisica Pura e Applicata, 2, 93-112, 1940.

Defant, A.: Physical Oceanography, Vol. 2. Pergamon, New York, 1961.

Del Ricco, R.: A numerical model of the vertical circulation of tidal strait and its application to the Messina Straits, Nuovo Cimento Soc. Ital. Fis., 5C, 21-45, 1982.

Di Sarra, A., Pace, A., and Salusti, E.: Long internal waves and columnar disturbances in the Strait of Messina, J. Geophys. Res., 92, 6495-6500, 1987.

Echevarría, F., Lafuente, J. G., Bruno, M., Gorsky, G., Goutx, M., González, N., García, C. M., Gómez, F., Vargas, J. M., Picheral, M., Striby, L., Varela, M., Alonso, J. J., Reul, A., Cózar, A., Prieto, L., Sarhan, T., Plaza, F., Jiménez-Gómez, F.: Physicalbiological coupling in the Straits of Gibraltar, Deep-Sea Res. II, 49, 4115-4130, 2002.

Farmer, D. M., D’Asaro, E. A., Trevorrow, M., and Dairiki, G. T.:
Three-dimensional structure in a tidal front, Cont. Shelf Res., 15(13), 1649-1673, 1995.

Farmer, D., Pawlowicz, R., and Jiang, R.: Tilting separation flows: a mechanism for intense vertical mixing in the coastal ocean, Dyn. Atmos. Oceans, 36(1-3), 43-58, 2002.

Fischer, R. A.: Statistical Methods for Research Workers. Oliver \& Boyd, Edinburgh, 1946.

Genovese, S., Cortese, G., Crisafi, E., De Domenico, E., De Domenico, M., Genovese, L., La Ferla R., and Pulicanò, G.: Caratterizzazione delle popolazioni microbiche in acque ioniche e tirreniche, Nova Thalassia, 6, 425-433, 1984.

Gomez, F., Gorsky, G., Garcia-Gorriz, E., and Picheral, M.: Control of the phytoplankton distribution in the Straits of Gibraltar by wind and fortnightly tides. Estuarine, Coastal and Shelf Science, 59, 485-497, 2004.

Grasshoff, K.: Determination of nitrate, in: Methods of seawater analysis, edited by: Grasshoff, K., Ehrhardt, M., and Grasshoff, K., Verlag Chemie, Weinheim, 143-150, 1983.

Griffa, A., Marullo, S., Santoleri, R., and Viola, A.: Note on internal nonlinear tidal waves generated at the Straits of Messina, Continental Shelf Research, 6, 677-687, 1986.

Guglielmo, L., Manganaro, A., and De Domenico, E.: The straits of Messina ecosystem: present knowledge for an ecohydrodynamical approach. Proceedings of symposium held in Messina, 4-6 April 1991. Università degli Studi di Messina, Dipartimento di Biologia Animale ed Ecologia Marina, Messina, 1995.

Hopkins, T. S., Salusti, E., and Settimi, D.: Tidal forcing of the water mass interface in the Straits of Messina, J. Geophys. Res., 89, 2013-2024, 1984.

Innamorati, M., Ferrari, I., Marino, D., and Ribera d'Alcalà, M. (Eds): Metodi nell'Ecologia del Plancton Marino, Nova Thalassia, Trieste, 1990.

Innamorati, M., Massi, L., and Nuccio, C.: Indipendenza delle biocenosi fitoplanctoniche dalle masse d'acqua circostanti le isole Eolie, Atti A.I.O.L., 11, 645-654, 1996.

Kinder, T. and Bryden, H.: Aspiration of deep waters through straits, in: The Physical Oceanography of Sea Straits, edited by: Pratt, L. J., Kluwer, Boston, 295-319, 1990.

Koike, I., Furuya, K., Otobe, H., Nakai, T., Memoto, T., and Hattori, A.: Horizontal distributions of surface chlorophyll a and nitrogenous nutrients near Bering Straits and Unimak Pass. Deep Sea Research Part A, Oceanographic Research Papers, 29(2), 149$155,1982$.

Kontoyiannis, H., Balopoulos, E., Gotsis-Skretas, O., Pavlidou, A., Assimakopoulou, G., and Papageorgiou, E.: The hydrology and biochemistry of the Cretan Straits (Antikithira and Kassos Straits) revisited in the period June 1997-May 1998, J. Mar. Syst., 53(1-4), 37-57, 2005.

Lee, H.-J., Chao, S.-Y., Fan, K.-L., Wang, Y.-H., and Liang, N.-K.: Tidally induced upwelling in a semi-enclosed basin: Nan Wan Bay, J. Oceanogr., 53, 467-480, 1997.

Levasseur, M. E. and Therriault, J.-C.: Phytoplankton biomass and nutrient dynamics in a tidally induced upwelling : the role of the $\mathrm{NO}_{3}>: \mathrm{SiO}_{4}$ ratio, Mar. Ecol. Prog. Ser., 39, 87-97, 1987.

Magazzù, G., Bruni, V., Piccione, A., Platt, T., Irwin, B., and Rao, S.: Picoplankton: Contribution to Phytoplankton Production in the Straits of Messina, Mar. Ecol., 8(1), 21-31, 1987.

Magazzù, G., Bruni, V., Decembrini, F., and Panella, S.: La pro- 
duzione primaria del picoplancton fotosintetico nei mari italiani, Oebalia, 4, 463-478, 1989.

Magazzù, G., Aubert, M., and Decembrini, F.: The effect of tidal movements on planktonic transfer through the Straits of Messina, in: The straits of Messina ecosystem: present knowledge for an eco-hydrodynamical approach, edited by: Guglielmo, L., Manganaro, A., and De Domenico, E., Proceedings of symposium held in Messina, 4-6 April 1991. Università degli Studi di Messina, Dipartimento di Biologia Animale ed Ecologia Marina, Messina, 191-202, 1995.

Mosetti, F.: Some news on the currents in the Straits of Messina, Bollettino di Oceanologia Teorica ed Applicata, 6(3), 119-201, 1988.

Nicolò, L., and Salusti, E.: Field and satellite observations of large amplitude internal tidal wave trains south of the Straits of Messina, Mediterranean Sea, Ann. Geophys., 9, 534-539, 1991, http://www.ann-geophys.net/9/534/1991/.

Raffa, F. and Hopkins, T. S.: Circulation and water mass structure over a narrow shelf, Augusta Gulf (Sicily), Chemistry and Ecology, 20 (Supplement 1), S249-S266, 2004.

Reul, A., Rodriguez, V., Jimenez-Gomez, F., Blanco, J. M., Bautista, B., Sarhan, T., Guerrero, F., Ruiz, J., and GarciaLafuente, J.: Variability in the spatio-temporal distribution and size-structure of phytoplankton across an upwelling area in the NW-Alboran Sea, (W-Mediterranean), Continental Shelf Res., 25, 589-608, 2005.
Ruiz, J., Echevarría, F., Font, J., Ruiz, S., García, E., Blanco, J. M., Jiménez-Gómez, F., Prieto, L., González-Alaminos, A., García, C. M., et al.:. Surface distribution of chlorophyll, particles and gelbstoff in the Atlantic jet of the Alborán Sea: from submesoscale to subinertial scales of variability, J. Mar. Syst., 29(1-4), 277-292, 2001.

Sapia, A. and Salusti, E.: Observation of nonlinear internal solitary wave trains at the northern and southern mouths of the Straits of Messina, Deep-Sea Res., 34, 1081-1092, 1987.

Strickland, J. H. D. and Parsons, T. R.: A practical handbook of seawater analysis. 2nd ed. Bull. Fish. Res. BD, Ottawa, 167, 1972.

Tang, D. L., Kawamura, H., and Guan, L.: Long-time observation of annual variation of Taiwan Straits upwelling in summer season, Adv. Space Res., 33(3), 307-312, 2004.

Tomasin, A. and Tomasino, M.: Nuove conoscenze idrografiche relative alla stretto di Messina, Atti A.I.O.L., 4(10), 1-9, 1983.

Vargas-Yáñez, M., Viola, T. S., Jorge, F. P., Rubín, J. P., and GarcíaMartínez, M. C.: The influence of tide-topography interaction on low-frequency heat and nutrient fluxes. Application to Cape Trafalgar, Continental Shelf Res., 22(1), 115-139, 2002.

Vercelli, F.: Crociere per lo studio dei fenomeni nello Stretto di Messina. II. Il regime delle correnti e delle maree nello Stretto di Messina. Commissione Internazionale del Mediterraneo, Venezia, 1925.

Vercelli, F. and Picotti, M.: Crociere per lo studio dei fenomeni nello Stretto di Messina. II. Il regime fisico-chimico delle acque nello Stretto di Messina. Commissione Internazionale del Mediterraneo, Venezia, 1926. 